\title{
Do Real and Fictitious Plant Brands Differ in Brand Recognition, Awareness, Purchase Intention, and Visual Activity?
}

\author{
Bridget K. Behe ${ }^{1}$ \\ Department of Horticulture, Michigan State University, 1066 Bogue Street, \\ East Lansing, MI 48824-1325
}

Patricia T. Huddleston

Department of Advertising and Public Relations and Department of Media and Information Studies, Michigan State University, 404 Wilson Road, East Lansing, MI 48824

Charles R. Hall

Department of Horticultural Sciences, Texas A\&M University, 2133 TAMU, College Station, TX 77843

Hayk Khachatryan

Food and Resource Economics Department and Mid-Florida Research and Education Center, 2725 Binion Road, Apopka, FL 32703

Benjamin Campbell

Department of Agricultural and Applied Economics, 147 Cedar Street, Athens, GA 30602

Additional index words. Buddleia davidii, Callibrachoa, consumer, conjoint analysis, green industry, Impatiens hawkeri, Rosa, survey

Abstract. Brands differentiate products from each other and help create the perception of added value. They influence product choice at the point of purchase with $>70 \%$ of all buying decisions made in the store. Brands are often one of a few pieces of information consumers use to make product choices. Prior research showed that consumers had a greater likelihood to buy plant brands they had previously seen. To advance both the academic and practitioners' understanding of plant brands, we sought to investigate the role of real and fictitious brands and their effects on visual activity and purchase intentions. Would simply including information on the container (e.g., fictitious brand) sway visual activity and purchase intentions? To investigate this notion, we conducted an in-person survey with a conjoint design in four states during May and June, 2015, using two flowering annuals and two flowering shrubs. Our goals were to assess consumers' expressed and implicit preferences and, at the same time, monitor their gaze to determine how subjects used the real and fictitious brands as cues in their purchase decision. We showed 214 study participants digital images of 16 plants, varying the plant type, brand, and price; asked about brand awareness and familiarity; collected demographic and plant purchase information; and recorded their gaze as they viewed the images. We segmented the sample into three clusters, comparing their brand awareness and familiarity, conjoint analysis results, and the two visual measures: time to first fixation (TFF) and total fixation duration (TFD) on the container. The three clusters identified varied in their level of brand recognition and awareness but were similar in the relative importance and part-worth utility (PWU) mean scores, indicating a relatively similar decision process. The visual activity varied slightly by brand, but the fictitious brand captured and held visual attention similarly to the two established national brands.

Slower sales growth in the Green Industry may be an indication that a market has matured, bringing increased competition among companies for consumers' dollars (Hodges et al., 2009). An influx of brands is likely to occur in mature industries in an effort to differentiate products from competitors and enhance the perceived product value (Kotler and Keller, 2009). Branding helps to create the perception of added value and distinguish a company's products from competitors' products. Differentiation and enhancing perceived value through branding may be successful actions for a company striving to increase sales in a mature market. In horticulture, anecdotal evidence suggests that plant branding appears to be increasing.

With $>70 \%$ of all buying decisions made at the point of purchase (POP), marketers have increased their in-store marketing budgets (e.g., signs, $\log$ os, and brands) from $\approx 3 \%$ in 2004 to $\approx 8 \%$ in 2010 (Ståhlberg and Maila, 2012). Marketers use brands at the POP to facilitate consumers' buying decisions. In the marketing literature, research findings support the notion that consumers first identify necessary information before they cognitively process it, then they arrive at a purchase decision (Lin and Chen, 2006; Olson and Jacoby, 1972). Some of the information used in the purchase decision includes brands. Therefore, it may be important for academics and practitioners to know which pieces of information at the POP, especially regarding plant brands, influence consumers in their purchase decisions.

Bisson et al. (2002) said, "The challenge to wine producers in this new century is daunting - to understand the fundamental motivation behind consumer choice and to produce wines of enhanced attractiveness while simultaneously developing and implementing sustainable production practices for both grape growing and wine making." With an abundance of choices in wines, capturing attention among the plethora of choices is a challenge. Pictorial and text branding are both prevalent in that industry, e.g., in the \$54 billion industry (Mintel, 2014), where consumers most often make their purchase decision at the point of sale (Chaney, 2000) brand logos often depict images of animals and plants that have nothing to do with the wine. The wine marketers' efforts to attract attention are due, in part, to the vast number of product choices in stores, which can be overwhelming for any consumer. Thus, their actions are focused primarily on attracting consumers' attention, but how does capturing consumers' attention influence purchase intention? Given the overwhelming choices in the horticulture industry, could the focus on grabbing attention influence sales? If wine marketers use animals on their labels, would that strategy be effective for plants in capturing attention? Could a fictitious brand (with a unicorn) act in the same manner as a nationally recognized brand to gain consumers' attention and influence their purchase motivations? While there have been a few studies on plant brands (Behe et al., 2016; Collart et al., 2010), industry and academia need more information regarding the impact that brands have on consumer perceptions or intentions to purchase plants.

\section{Literature Review}

Branding. The American Marketing Association defines a brand as a "name, term, design, symbol, or any other feature that identifies one seller's good or service as distinct from those of other sellers" (AMA, 2014). The brand name or logo can represent an information "chunk" in consumer decisionmaking (Simon, 1974), because consumers can infer product characteristics partially based on the brand (Jacoby et al., 1971). Brands serve as one type of information cue (extrinsic) for consumers, guiding and shaping their expectations about product performance (Kapferer, 2012). Previous research reported that brands 
play a crucial role in providing cues when consumers make purchase decisions (Dodds and Monroe, 1985; Dodds et al., 1991; Jacoby et al., 1977; Keller, 2013). Well-crafted and well-managed brands give companies an advantage in the market (Holmberg, 2002; Kotler and Keller, 2009) and retailers often manipulate displays to bring attention to brands they are marketing (Chandon et al., 2009; Clement et al., 2013; Drèze et al., 1993). Branding has been investigated substantially on nonhorticultural products; a recent and comprehensive summary of the peer-reviewed literature compiled 392 studies of the effects of branding on consumers (Fetscherin and Heinrich, 2015).

Prior studies have demonstrated that consumers use very few pieces of information making a purchase decision (Hansen, 1969; Olson and Jacoby, 1972), and among those cues the most often used are brand and price (Dodds and Monroe, 1985; Jacoby et al., 1974; Kardes et al., 2004; Olson and Jacoby, 1972). Price effects on plant purchase intention (Behe et al., 2005b, Behe et al., 2013, Getter and Behe, 2013; Mason et al., 2008; Rihn et al., 2015; Wollaeger et al., 2015) have been investigated more than price and brand in combination (Behe et al., 2016; Collart et al., 2010). Prior research suggests that brand recognition positively influences purchase behavior (Hoyer and Brown, 1990). Recognition of a brand, or anything else, can be defined as a mode of attention or "identifying something by its kind (name) and in view of the use to which it could be put" (Krippendorff, 2005).

Some researchers maintain that salient brands, those that are on the "top of mind," are the real purchase decision drivers (Chandon and Wansink, 2002; Keller, 2013; Nedungadi, 1990). Brand saliency may be an indication of brand awareness. Brand awareness goes beyond simple recognition and incorporates what consumers know about a brand. Known brands are more likely to be selected, regardless of the consumer's quality perception of both known and unknown brands (Hoyer and Brown, 1990). Furthermore, their study showed that when an inexperienced decision maker selected between a known and an unknown brand, s/he nearly always selected the known brand. However, the study did not include any fictitious brands. Including a fictitious brand is beneficial because it reveals if consumers' responses are truly based on the presence of the specific/real brand or if consumers assume product attributes just because it has a brand. Thus the question remains, do consumers react similarly to real

\footnotetext{
Received for publication 30 Nov. 2016. Accepted for publication $20 \mathrm{Jan} .2017$.

This project was also supported by the USDA National Food and Agriculture, Hatch Project Number MICL 02085, and by Michigan State University AgBioResearch.

We thank the Horticultural Research Institute for their generous funding of this research.

${ }^{1}$ Corresponding author. E-mail: behe@msu.edu.
}

and fictitious brands? Is any brand (i.e., real or fictitious) better than no brand?

To date, there have been two studies on national and regional plant brands. Collart et al. (2010) showed that Texas consumers who shopped for ornamental plants weekly or monthly had a higher level of brand awareness for state brands than consumers who shopped for plants less often. Furthermore, consumers who had higher state brand awareness were willing to pay more for branded plants. In their study, the two brands effectively differentiated products creating a price premium of $\approx 10 \%$. Additionally, subjects aged 40-55 years were least likely to be aware of brands while subjects aged $\geq 55$ were willing to pay the least for branded plants. Another study by Behe et al. (2016) showed that plant brand recognition varied by age group with older consumers (49-64 years old) recognizing one national plant brand while younger age cohorts (36-24 and 37-48 years old) recognized another national brand more frequently. Individuals who had noticed the plant brands before the study had a higher buying likelihood for branded plants compared with those who had not noticed the plant brands before the study. The younger age cohorts were more likely to buy branded herb and vegetable plants than the older age cohort. A conjoint analysis showed that plant type was the most important product attribute to consumers. Price and brand were similarly important but less important than plant type. Having no brand on the container detracted $\$ 0.20$ from the perceived value of the plants, whereas the brands added up to $\$ 0.15$ to the perceived plant value.

Visual attention. Visual attention is an essential part of the purchase process because "where the eye stops, the sale begins" (Pieters et al., 2010, p. 248). Eye movement is subconscious (Jacob, 1993) but also deliberate and task specific (Jacob, 1990). Gaze duration on an area of interest can be an important indicator of consumers' visual attention and information processing (Fischer and Weber, 1993). Furthermore, the amount of time spent looking at a certain area of a product can be an effective predictor of purchase behavior or intention (Armel et al., 2008; Behe et al., 2013; Clement et al., 2013; Lin and Chen, 2006; Rihn et al., 2016). Thus, we proposed to track consumers' eye movements as an objective physiological measure which may be influenced by different product cues, especially the brand. Visual attention can be measured in several ways; two of the more common metrics are TFF and TFD (Wedel and Pieters, 2008). TFF is an indication of visual capture, showing the length of time it takes (in milliseconds) for an element in a scene to be first viewed. Total fixation duration (TFD) is a measure of visual retention or the length of time (in milliseconds) that an element in a scene is viewed in total.

We hypothesized that consumers would not vary in their level of brand recognition (H1a) and awareness (H1b) and purchase intentions (H1c). We further hypothesized that the fictitious brand would not influence purchase intention (H2). Additionally, we hypothesized that there would be no difference in the likeliness to buy (LTB) real and fictitious brands (H3). Furthermore, we hypothesized that all consumers would find the brand similarly quickly (i.e., their gaze would be as fast to the brand compared with others) (H4) and would look at the brand the same length of time (H5).

\section{Materials and Methods}

A conjoint study with an in-person survey was used to better understand the role of real and fictitious plant brand recognition on consumers' intention to purchase a flowering annual or shrub. All experimental procedures and protocols were approved by the university's institutional review board. A total of 16 images were developed using a conjoint design, which is a statistical method used to determine preferences for products with a given set of attributes (Kuhfeld, 2010). It defines consumers' overall preference for a particular product as the sum of the PWU scores for each product attribute level (Gaasbeck and Bouwman, 1991; Hartigan, 1975). Conjoint analysis has been used to understand the purchase drivers and willingness to pay for a wide range of horticultural products, including Christmas trees (Behe et al., 2005b), landscapes (Behe et al., 2005a), mixed flowering annual containers (Mason et al., 2008), impatiens alternatives (Getter and Behe, 2013), eco-friendly plant production practices (Behe et al., 2013; Rihn et al., 2015, 2016; Yue et al., 2010), as well as vegetable and herb plant brands (Behe et al., 2016). For the present study, we built on Behe et al. (2016) and used a combination of product attributes and levels that represented two flowering annuals (Callibrachoa and Impatiens hawkeri) and two flowering shrubs (Buddleia davidii and Rosa Oso Easy Red) $\times$ four brands (two established national brands: Proven Winners and Monrovia; one fictitious brand Unicorn; and a generic container $) \times$ three prices $(\$ 5.99, \$ 9.99$, and \$13.99) factorial design. Although all 48 combinations could have been presented to subjects, we developed partial factorial design of 16 combinations using SPSS software (Version 22; SPSS Inc, Chicago, IL). This retained the ability to assess all attributes in the complete design but reduced the time and potential for subject fatigue (Chrzan and Orme, 2000).

The 16 images were presented to subjects in a randomized order on a computer monitor equipped with a Tobii $\mathrm{X} 1$ eye-tracking device (Tobii.com, Stockholm, Sweden) in a Latin Square design method of Tobii Studio (Tobi Pro, 2015). Each digital image consisted of a picture of the flowering plant in a white container photographed against a black background with a price shown in the lower right region of the image (Fig. 1). After photographing the plants against a black background, Adobe Photoshop (Adobe Systems, 
San Jose, CA) was used to digitally alter the container color and add brand and price information. Before stimuli presentation, respondents were given instructions and
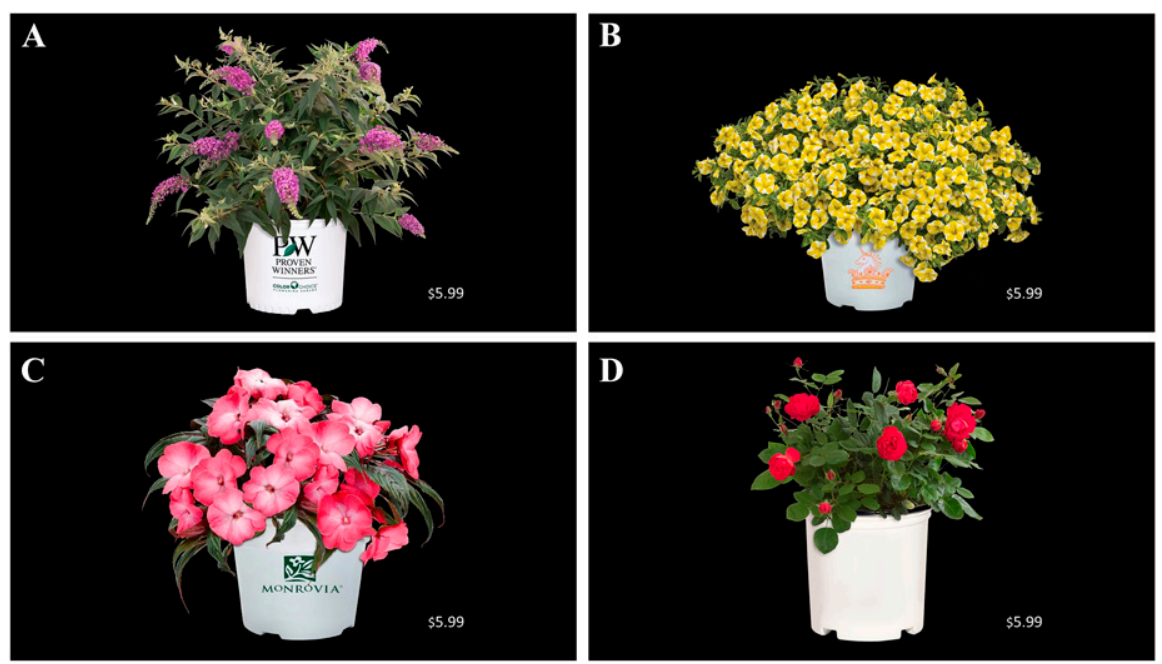

Fig. 1. Examples of plant images in branded and generic pots at $\$ 5.99$ price point used in an in-person survey.

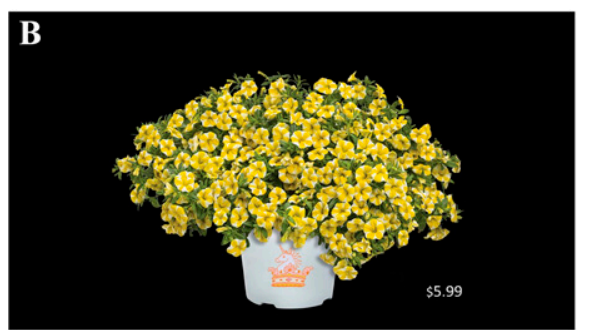

three practice images to better understand the process. Participants were asked to view each image and respond verbally with their LTB using the Juster scale (Brennan and
Esslemont, 1994), which is an 11-point scale (ranging from 0 to 10 , with 10 representing $10 / 10$ or "nearly certain" they would buy the product). The images were arrayed differently for each of four test locations.

After completing the visual portion of the study, we measured brand recognition and awareness. Specifically, subjects were asked to indicate if they had seen the brand logos shown before they began the study and how familiar they were with each plant brand. We also collected individual demographic and plant purchase information.

Data were collected in May and June, 2015, in Storrs, CT; Apopka, FL; East Lansing, MI; and College Station, TX. Respondents totaled 226, with 50 from Connecticut, Florida, and Texas, and 76 from Michigan. However, only 215 of 226 participants completed the visual portion, and one subject was eliminated due to identical responses for all 16 images $(\mathrm{SD}=0)$. Therefore, the total number of respondents used for analyses totaled 214. No selection criteria were used (e.g., plant purchases) to recruit participants.

Data analysis. Data analyses were generated using SAS software v. 9.4, Windows

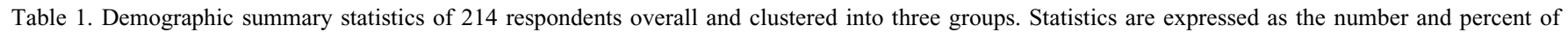
individuals in cluster, or mean and SE.

\begin{tabular}{|c|c|c|c|c|c|c|c|c|c|}
\hline Explanatory variable & $\begin{array}{c}\text { Overall } \\
(\mathrm{N}=214)\end{array}$ & $\begin{array}{l}\text { Median, } \\
\text { mode }\end{array}$ & $\begin{array}{c}\text { Results } \\
\text { statistic, } P \text { value }\end{array}$ & $\begin{array}{l}\text { Cluster } 1 \\
(\mathrm{n}=37)^{\mathrm{z}}\end{array}$ & $\begin{array}{l}\text { Cluster } 2 \\
(\mathrm{n}=112)^{\mathrm{z}}\end{array}$ & $\begin{array}{l}\text { Cluster } 3 \\
(\mathrm{n}=65)\end{array}$ & Test & $\begin{array}{l}\text { Results } \\
\text { value, } P\end{array}$ & MV \\
\hline \multicolumn{10}{|l|}{ Gender, female } \\
\hline $\mathrm{n}(\%)$ & $148(70.1)$ & \multirow[b]{2}{*}{1,1} & \multirow{2}{*}{$\chi^{2}=34.24,<0.0001$} & $25(69.4)$ & $74(67.3)$ & $49(75.4)$ & \multirow[t]{2}{*}{$\chi^{2}$} & \multirow[t]{2}{*}{$1.29,0.5237$} & \multirow[t]{2}{*}{$1,2,0$} \\
\hline Mean (SD) & $0.70(0.46)$ & & & $1.7(0.4)$ & $1.7(0.4)$ & $1.8(0.4)$ & & & \\
\hline Age & & & & $50.3(1.1) \mathrm{A}$ & $38.4(1.0) \mathrm{B}$ & $43.2(1.0) \mathrm{AB}$ & $\mathrm{F}$ & $8.65,0.0002$ & \multirow[t]{3}{*}{0} \\
\hline $\begin{array}{r}\text { Mean (SE) (A, C, B } \\
\text { without Tukey's) }\end{array}$ & & & & $50.3(1.1) \mathrm{A}$ & $38.4(1.0) \mathrm{B}$ & $43.2(1.0) \mathrm{AB}$ & $\mathrm{F}$ & $8.65,0.0002$ & \\
\hline Mean (SD) & $44.4(15.5)$ & $41.5,26.0$ & & & & & & & \\
\hline \multicolumn{10}{|l|}{ Ethnicity, n (\%) } \\
\hline Caucasian & $157(73.7)$ & & \multirow[t]{2}{*}{$\chi^{2}=47.89,<0.0001$} & $32(15.0)$ & $73(34.3)$ & $52(24.4)$ & \multirow[t]{2}{*}{$\chi^{2}$} & \multirow[t]{2}{*}{$9.20,0.0100$} & \multirow[t]{2}{*}{$0,0,1$} \\
\hline Other & $56(26.3)$ & & & $5(2.4)$ & $39(18.3)$ & $12(5.6)$ & & & \\
\hline Adults, mean (SD) & $2.3(0.9)$ & 2,2 & & $2.1(0.9) \mathrm{AB}$ & $2.4(1.0) \mathrm{A}$ & $2.1(0.7) \mathrm{B}$ & & $4.00,0.0197$ & 0 \\
\hline Children, mean (SD) & $0.7(1.3)$ & 1,1 & & $0.8(1.6)$ & $0.7(1.3)$ & $0.8(1.3)$ & $\mathrm{F}$ & $0.41(0.6645)$ & $0,1,1$ \\
\hline \multicolumn{10}{|l|}{ Region, n (\%) } \\
\hline Metropolitan & $25(11.8)$ & & \multirow[t]{3}{*}{$\chi^{2}=61.25,<0.0001$} & $6(16.2)$ & $13(11.7)$ & $6(9.4)$ & $\chi^{2}$ & $1.06,0.5897$ & $0,1,1$ \\
\hline Suburban & $118(55.7)$ & & & $20(54.1)$ & $66(59.5)$ & $32(50.0)$ & $\chi^{2}$ & $1.52,0.4680$ & $0,1,1$ \\
\hline Rural & $69(32.6)$ & & & $11(29.7)$ & $32(28.8)$ & $26(40.6)$ & $\chi^{2}$ & $2.74,0.2547$ & $0,1,1$ \\
\hline Education, mean (SD) & $4.7(1.4)$ & 5,5 & & $4.8(1.4)$ & $4.9(1.4)$ & $4.4(1.4)$ & $\mathrm{F}$ & $2.41(0.0927)$ & $0,0,1$ \\
\hline \multicolumn{10}{|l|}{ Education level, n (\%) } \\
\hline $\begin{array}{l}\text { Some high school, } \\
\text { high school, or GED }\end{array}$ & $20(9.4)$ & & $140.51,<0.001$ & $3(8.1)$ & $10(8.9)$ & $7(10.9)$ & $\chi^{2}$ & $0.28,0.8695$ & $0,0,1$ \\
\hline $\begin{array}{l}\text { Some college or 2-yr } \\
\text { degree }\end{array}$ & $51(23.9)$ & & $57.84,<0.0001$ & $9(24.3)$ & $22(19.6)$ & $20(32.2)$ & $\chi^{2}$ & $3.02,0.2213$ & $0,0,1$ \\
\hline 4-yr college degree & $76(35.7)$ & & $17.47,<0.0001$ & $15(40.5)$ & $41(36.6)$ & $20(31.2)$ & $\chi^{2}$ & $0.97,0.6157$ & $0,0,1$ \\
\hline University degree $(>4 \mathrm{yr})$ & $66(31.0)$ & & $30.80,<0.0001$ & $10(27.0)$ & $39(34.8)$ & $17(26.6)$ & $\chi^{2}$ & $1.63,0.4432$ & $0,0,1$ \\
\hline Income, mean (SD) & $\begin{array}{l}\$ 73,061 \\
(\$ 3,013)\end{array}$ & $\begin{array}{l}\$ 70,000 \\
\$ 50,000\end{array}$ & & $\begin{array}{l}\$ 78,485 \\
(\$ 36,411)\end{array}$ & $\begin{array}{l}\$ 71,132 \\
(\$ 44,749)\end{array}$ & $\begin{array}{l}\$ 73,509 \\
(\$ 40,730)\end{array}$ & $\mathrm{F}$ & $0.38,0.6814$ & $4,6,8$ \\
\hline
\end{tabular}

${ }^{\mathrm{z}}$ Analysis total may be less due to missing values (MVs). MVs are listed in order of cluster number. Percentages may not add up to 100 due to rounding. Different letters within rows indicate significant differences of means at $\alpha=0.05$. The analyses in this table were generated using either the FREQ (chi square and Fisher's exact test) or GLIMMIX (F test) procedure of SAS software. Chi square tests were used with categorical variables in 3 cluster $\times 2$ response $(0=$ no; $1=$ yes $)$ contingency tables; only the affirmative (1) values are presented above. If the sample size (table cell count) was less than 5, Fisher's exact test was used. Analyses of variance between cluster means were tested by the F test using the Tukey adjustment. (SAS and all other SAS Institute Inc. product or service names are registered trademarks or trademarks of SAS Institute Inc., Cary, NC.)

Values in bold are significant at $P=0.05$ or lower. 
version 6.1 .7601 on the X64_7PRO platform (SAS Institute Inc.). Participant preferences for the plant products were gained using the TRANSREG Procedure (METHOD = morals to fit each model individually, SAS/STAT ${ }^{\circledR} 14.1$ User's Guide, 2015) in SAS software. The dependent variable consisted of the LTB values, whereas the independent class variables included the attributes plant type, brand, and price. Independent variables were effects coded resulting in the summation of PWU within each attribute being constrained to zero. The percent relative importance for each attribute (plant, brand, and price) and the PWU's at each attribute level were incorporated into the main data set for comparisons between respondent segregation by cluster analysis. A k-means model of the FASTCLUS Procedure of SAS software (SAS/STAT ${ }^{\circledR} 14.1$ User's Guide, 2015) was used to generate clusters.

\section{Results}

Demographic characteristics. The sample was composed of $70.1 \%$ females and had a mean age of 44.4 years (Table 1). Nearly three-fourths of the sample were Caucasian and had an average of 0.7 children. Slightly more than half of the sample resided in a suburban region and $66.7 \%$ had at least a 4 -year college degree. The 2015 mean household income for the sample was $\$ 73,061$, whereas their median income was $\$ 70,000$. According to the U.S. Census (2016), the U.S. population consists of $50.8 \%$ female and $77.1 \%$ Caucasian with a median income of $\$ 53,482$. Although the preponderance of plant consumers are female (Butterfield and Baldwin, 2015), without the variances of the reported census information, it was not possible to test for statistical differences between the sample and the U.S. population.

Plant purchases: type and location. We wanted to understand the types of plants the participants had purchased in the year before the study as well as the types of retail outlets

Table 2. Response summary of means (SE) for 214 respondents overall and by cluster memberships.

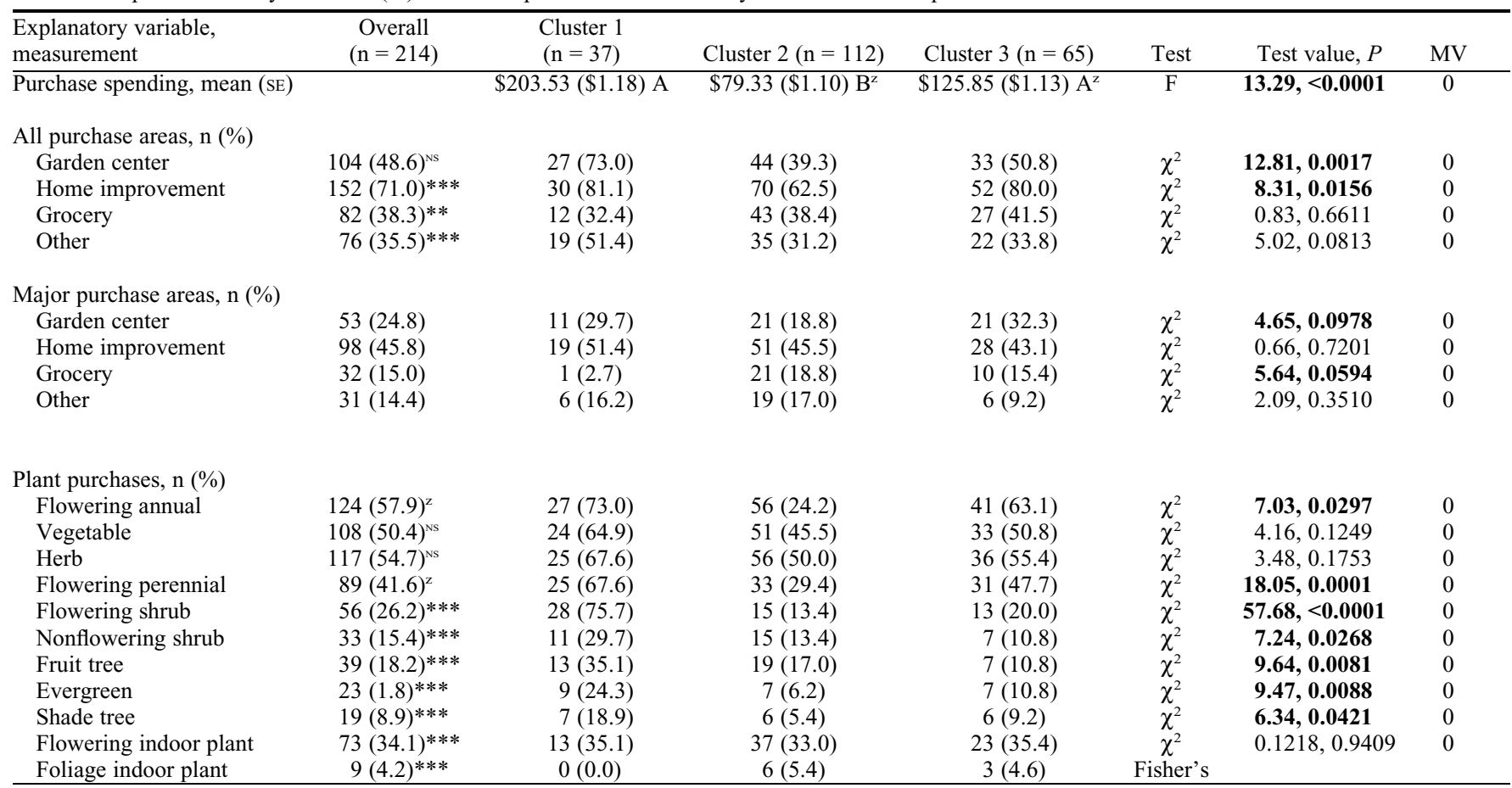

Different letters within rows indicate significant differences of means at $\alpha=0.05$. The analyses in this table were generated using either the FREQ (chi square and Fisher's exact test) or GLIMMIX (F test) procedure of SAS software. Chi square tests were used with categorical variables in 3 cluster $\times 2$ response $(0=$ no; $1=$ yes) contingency tables; only the affirmative (1) values are presented above. If the sample size (table cell count) was less than 5, Fisher's exact test was used Analyses of variance between cluster means were tested by the F test using the Tukey adjustment. (SAS and all other SAS Institute Inc. product or service names are registered trademarks or trademarks of SAS Institute Inc., Cary, NC.)

Values in bold are significant at $P=0.05$ or lower.

** Significant at $P \leq 0.05$. NS not significant at $P \leq 0.05$.

${ }^{z} \mathrm{~A}, \mathrm{C}, \mathrm{B}$ without Tukey's.

Table 3. Percentage of 214 respondents who had seen or recognized brands presented in the survey, overall and by cluster. Which of these brands have you seen before today?

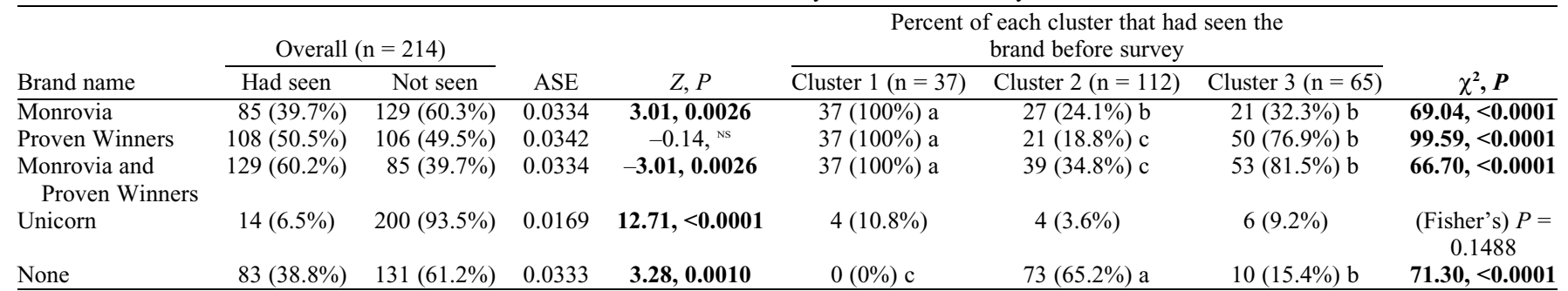

The analyses in this table were generated using FREQ procedure of SAS software. Binomial proportions ( 0.5$)$ were computed for the unclustered participants who had seen and not seen the brand name indicated. Chi square tests were used on the 3 clusters $\times 2$ responses $(0=$ not seen, $1=$ seen $)$ for each brand name; only the "Have seen" results are presented. If the sample size (table cell count) was less than 5, Fisher's exact test was used. (SAS and all other SAS Institute Inc. product or service names are registered trademarks or trademarks of SAS Institute Inc., Cary, NC.)

Values in bold are significant at $P=0.05$ or lower. 
from which they had purchased them (Table 2). Regarding consumer's plant-related purchases (excluding motorized equipment), $71 \%$ indicated they had made a garden-related purchase from a home improvement store, nearly $50 \%$ had made at least one purchase from a retail garden center, and over a third had purchased a plant- or garden-related supplies from a supermarket/grocery store. Nearly, half of the participants had primarily purchased plantrelated items from a home improvement store. Nearly one-quarter reported that most of their purchases were made from an independent garden center and only 15\% indicated that most of those purchases were made at the supermarket/grocery store.

Annual plants were the most frequently purchased type of plant with nearly $60 \%$ of the sample purchasing them (Table 2). Perennials were purchased by $41.6 \%$ of participants and slightly more than one-quarter of participants had purchased a flowering shrub. This is higher than the percentages reported by Butterfield and Baldwin (2015). Their study showed that annual flower transplants were purchased by $21 \%$ of a national panel while perennials were purchased by $16.8 \%$ of that same sample. Flowering trees/shrubs were bought by $6.7 \%$ of the study's participants (Butterfield and Baldwin, 2015).

Brand recognition and brand awareness. To test brand awareness and recognition, respondents were asked if they had seen any of the brands before the day of the study
(Table 3). Very few $(6.5 \%)$ reported that they noticed (recognized) the fictitious brand compared with the two established national brands (Monrovia 39.7\% and Proven Winners 50.5\%). Similarly, a very high percentage of respondents had no familiarity, experience, or knowledge about the fictitious brand compared with the Proven Winners and Monrovia brands (Table 4). So, most participants did not indicate either brand recognition or awareness with the fictitious brand.

In an effort to assess brand perceptions, study participants were asked their level of agreement with various brand statements pertaining to plants. Nearly all $(87.4 \%)$ of the subjects agreed or strongly agreed that "Plants don't need to have a brand name to be high quality" (Table 5). Similarly, the majority of respondents disagreed, strongly disagreed, or were neutral that "The well-known national plant brands are best for me." This suggests that branding may not influence the purchase intentions of respondents. Instead, respondents appeared to place more emphasis on the retail outlet rather than the brand because a high percentage (59.8\%) agreed or strongly agreed that "Nice garden centers and specialty stores offer me the best products" and "I trust the retailer to provide me with the best plants."

Conjoint analysis. The conjoint analysis was used to determine the relative importance and PWU scores for each of the three product attributes (plant, brand, and price) included in the study (Table 6). Consistent with Behe et al.
(2016), which used conjoint analysis to study plant brands on nonflowering vegetable and herb transplants, we found that the type of plant was the most important product attribute with the highest relative importance $(55.3 \%)$. This was followed by price $(27.1 \%)$ then brand $(17.6 \%)$. This was slightly different from what Behe et al. (2016) reported in that price and brand were similarly important. The lowest priced plants (\$5.99) had the highest PWU and were the most valued among the product choices and the highest priced products (\$13.99) were the least valued. The Proven Winners brand was preferred over the Unicorn brand, whereas the Monrovia brand was similar to both the Proven Winners, Unicorn, and generic or no brand. This indicates that the respondents' preferences derived from the conjoint analysis were not consistent with their stated preferences in that the generic or no brand plants were equally valued (i.e., similar mean utility score) as the real brands and fictitious brand. In other words, the conjoint results and the stated results were not consistent; one of the established national brands (Proven Winners) was valued more in the stated preference than the other national brand, the fictitious brand, and the generic plant.

Cluster analysis. To explore the possibility that the market was heterogeneous and not all consumers would have a similar perspective on plant brands, respondents were clustered into three groups, based on their answers to questions related to brand recognition and

Table 4. Comparisons between responses of all respondents to frequency and percentages.

\begin{tabular}{|c|c|c|c|c|c|c|}
\hline \multicolumn{7}{|c|}{ Overall frequency $(\%)(n=214)$} \\
\hline Question & \multicolumn{5}{|c|}{ Frequency } & $\chi^{2}, P$ \\
\hline \multicolumn{7}{|l|}{ With regard to Proven Winners } \\
\hline How experienced are you with them? & $131(61.2)$ & $33(15.4)$ & $13(6.1)$ & $26(12.2)$ & $11(5.1)$ & $234.97,<0.0001$ \\
\hline How knowledgeable are you about them? & $149(69.6)$ & $22(10.3)$ & $16(7.5)$ & $21(9.8)$ & $6(2.8)$ & $333.14,<0.0001$ \\
\hline Mean $(\%)$ & 63.1 & 12.6 & 7.8 & 11.4 & 5.1 & \\
\hline How experienced are you with them? & $155(72.4)$ & $19(8.9)$ & $13(6.1)$ & $19(8.9)$ & $8(3.7)$ & $369.64,<0.0001$ \\
\hline How knowledgeable are you about them? & $163(76.2)$ & $17(7.9)$ & $14(6.5)$ & $13(6.1)$ & $7(3.3)$ & $423.20,<0.0001$ \\
\hline Mean $(\%)$ & 72.6 & 9.3 & 5.9 & 8.3 & 3.9 & \\
\hline \multicolumn{7}{|l|}{ With regard to Unicorn } \\
\hline How familiar are you with them? & $209(97.6)$ & $3(1.4)$ & $1(0.5)$ & $1(0.5)$ & $0(0)$ & $602.67,<0.0001$ \\
\hline How experienced are you with them? & $210(98.1)$ & $2(0.9)$ & $2(0.9)$ & $0(0)$ & $0(0)$ & $404.34,<0.0001$ \\
\hline
\end{tabular}

Percentages may not add up to 100 due to rounding.

Values in bold are significant at $P=0.05$ or lower.

Table 5. Frequencies, percentages, mean, and SDS of 214 respondent choices for response options in a survey on plant brands and retail outlets.

\begin{tabular}{|c|c|c|c|c|c|c|}
\hline \multirow[b]{2}{*}{ Question } & \multicolumn{5}{|c|}{ Frequency $(\%)$} & \multirow[b]{2}{*}{ Mean (SD) } \\
\hline & Strongly disagree & Disagree & Neutral & Agree & Strongly agree & \\
\hline The well-known national plant brands are best for me & $29(13.6)$ & $67(31.3)$ & $92(43.0)$ & $21(9.8)$ & $5(2.3)$ & $2.56(0.93)$ \\
\hline The more expensive plant brands are usually my choices & $71(33.2)$ & $88(41.1)$ & $47(22.0)$ & $6(2.8)$ & $2(0.9)$ & $1.97(0.87)$ \\
\hline Differences among plant brands are large (over 100 due to rounding) & $15(7.0)$ & $59(27.6)$ & $99(46.3)$ & $34(15.9)$ & $7(3.3)$ & $2.81(0.90)$ \\
\hline Differences among plant brands are hard to judge & $2(0.9)$ & $24(11.2)$ & $52(24.3)$ & $112(52.3)$ & $24(11.2)$ & $3.62(0.86)$ \\
\hline The best plant brand is hard to determine & $1(0.5)$ & 17 (7.9) & $43(20.1)$ & $124(57.9)$ & 29 (13.6) & $3.76(0.80)$ \\
\hline Plants do not need to have a brand name to be high quality & $1(0.5)$ & $5(2.3)$ & $21(9.8)$ & $96(44.9)$ & $91(42.5)$ & $4.27(0.77)$ \\
\hline
\end{tabular}




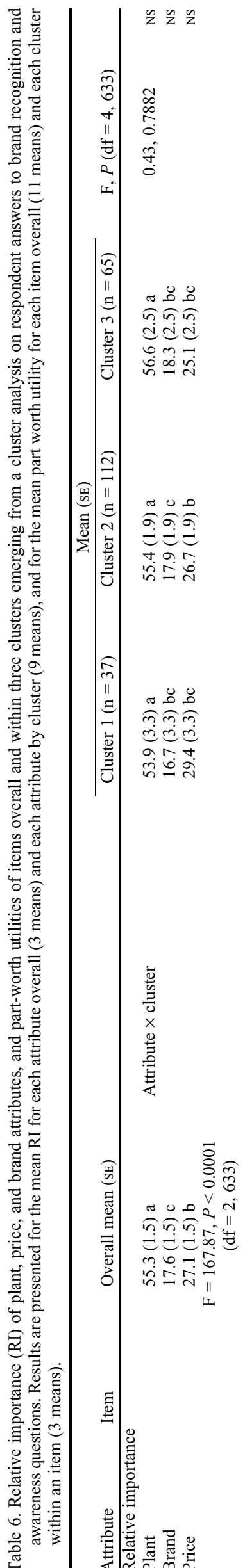

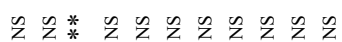

氙

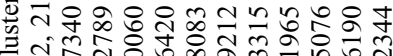

ग

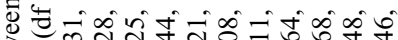

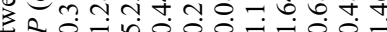
茫

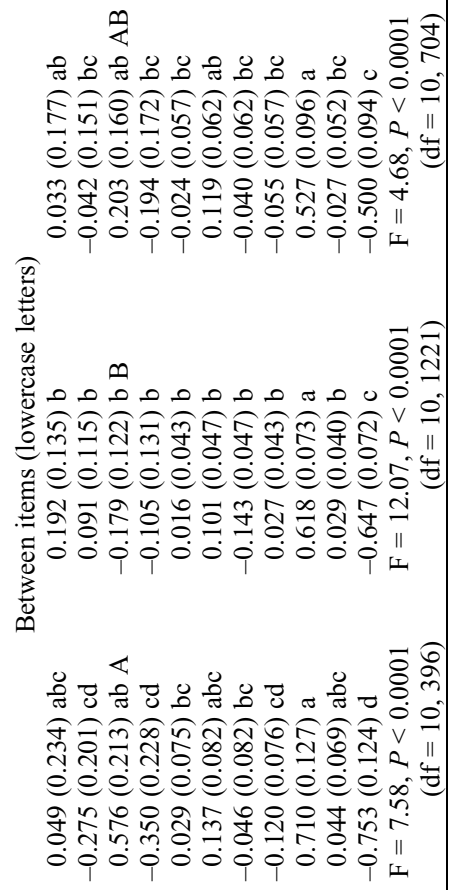

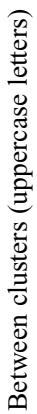

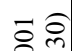

응

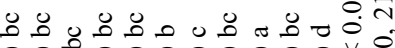

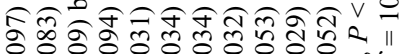

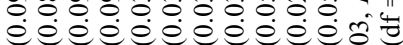

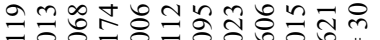

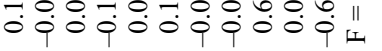

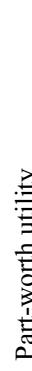

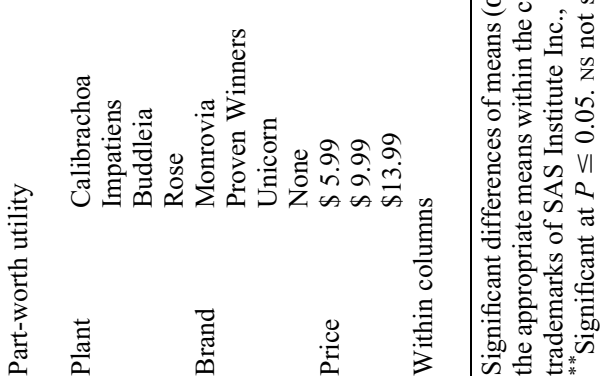

awareness (Tables 3 and 4) using the FASTCLUS procedure in SAS. This resulted in a three cluster solution (Cubic Clustering Criterion $=54.432$ ) with values $>3$ indicating a good cluster number solution.

The first cluster consisted of 37 subjects (17.2\% of the sample) and was labeled "Brand Savvy Buyers." Members were 7 to 12 years older than the other two clusters and much less likely to be Caucasian (Table 1). They spent the most on plant material (\$203) and were more likely to have purchased most of the plant types listed, including annuals, perennials, and flowering shrubs (Table 2). Half of the cluster members made most of their plant purchases from the home improvement store, whereas a third made most of their plant purchases from the independent garden center. This cluster also differed from the other two clusters in that all of its members indicated they had noticed the nationally known brands (Proven Winners and Monrovia) $(100 \%)$, but $10.8 \%$ had reported seeing the Unicorn brand (Table 3). Members of this cluster were also among the most brand-savvy participants, because the majority were more likely to be familiar with, experienced with, and knowledgeable about the two real national plant brands (Proven Winners and Monrovia), indicating a higher level of brand awareness (Table 7). Members of this segment valued the Buddleia more than members of cluster 2 (Table 6). Since they had spent the most on plants and had high brand awareness, they would be a valuable and potentially profitable market segment to target.

The second cluster to emerge was the largest and included 112 members $(52.3 \%)$ who were characterized as "Brand Unaware Non-buyers." Members of this cluster were the youngest in comparison with the other two clusters and had a high percentage of individuals who were Caucasian (Table 1). They spent the least on plants (\$79) and a third or fewer of the members had purchased most of the plants listed with the exception of herbs and vegetables (Table 2). In addition, only $18.8 \%$ of this cluster indicated they had seen the Proven Winners brand, whereas $34.8 \%$ had noticed one or both of the national brands (Table 3). In contrast to the other groups, the majority of this cluster's members were "not at all" aware (familiar/experienced with, and knowledgeable about) of the two nationally known plant brands shown in the study. Furthermore, over $75 \%$ of the members of this cluster agreed or strongly agreed that "differences among plant brands are hard to judge." Thus, this cluster was less aware of the two national brands before the study. They also valued Buddleia less than members of cluster 1 (Table 6).

The 65 members of the third cluster $(30.3 \%)$ indicated great reliance on brand name more so compared with the other clusters and were named "Brand Reliant Buyers." Members of this group were intermediate in age when compared with the other clusters and moderately likely to be Caucasian (Table 1). They were intermediate in their plant expenditures (\$125) and also in 
Table 7. Comparisons between responses of three cluster groups to survey questions by percentages. Responses were based on a 1 to 5 scale, where $1=$ not at all and $5=$ very much.

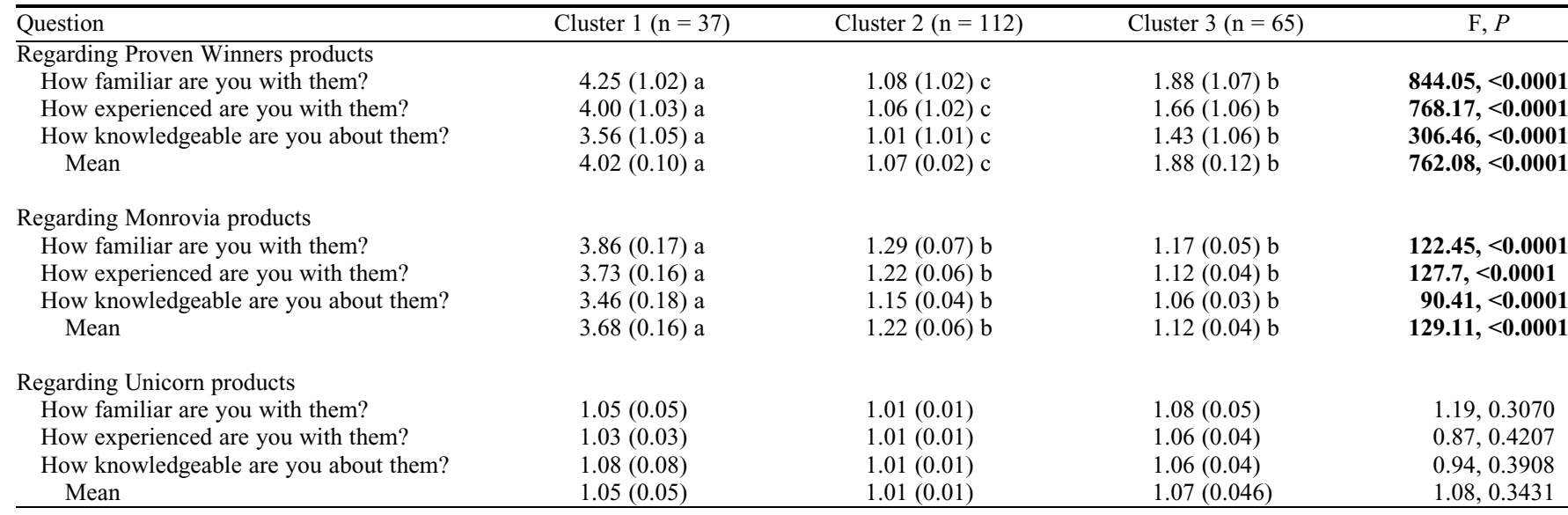

Different letters within rows indicate significant differences of means at $\alpha=0.05$. F and $P$ values are indicated to the right of each grouping. The analyses in this table were generated using GLIMMIX procedure of SAS software. Analyses of variance between cluster means were tested by the F test using the Tukey adjustment.

Values in bold are significant at $P=0.05$ or lower.

Table 8. Comparisons of those who looked at the pot (1) to those who did not (0) by the pot brand and cluster number $(\mathrm{N}=214)$

\begin{tabular}{|c|c|c|c|c|}
\hline \multirow{2}{*}{$\begin{array}{l}\text { Variable } \\
\text { Fixated on Pot } \\
\text { Yes }=1 \\
\text { No }=0\end{array}$} & \multicolumn{2}{|c|}{ Effect } & & $\begin{array}{r}\text { (df Num, Den) F, } P \\
(2,211) 4.23,0.0158\end{array}$ \\
\hline & $\begin{array}{l}\text { Brand } \\
N=856 \\
(214 \times 4 \text { brands }) \\
\text { Brand } \times \text { cluster no. }\end{array}$ & $\begin{array}{l}\text { Monrovia } \\
\mathrm{PW} \\
\text { Unicorn } \\
\text { No brand } \\
\\
\text { Monrovia } \times 1 \\
\text { Monrovia } \times 2 \\
\text { Monrovia } \times 3 \\
\mathrm{PW} \times 1 \\
\mathrm{PW} \times 2 \\
\mathrm{PW} \times 3 \\
\text { No brand } \times 1 \\
\text { No brand } \times 2 \\
\text { No brand } \times 3 \\
\text { Unicorn } \times 1 \\
\text { Unicorn } \times 2 \\
\text { Unicorn } \times 3\end{array}$ & $\begin{array}{l}0.48(0.02) \mathrm{b} \\
0.52(0.01) \mathrm{ab} \\
0.56(0.02) \mathrm{a} \\
\\
0.62(0.02) \mathrm{a} \\
0.61(0.02) \mathrm{a} \\
0.57(0.02) \mathrm{a} \\
0.28(0.02) \mathrm{b} \\
0.59(0.04) \mathrm{abcd} \\
0.59(0.02) \mathrm{bcd} \\
0.68(0.03) \mathrm{a} \\
0.51(0.04) \mathrm{d} \\
0.65(0.02) \mathrm{ab} \\
0.67(0.03) \mathrm{a} \\
0.29(0.04) \mathrm{e} \\
0.28(0.02) \mathrm{e} \\
0.26(0.03) \mathrm{e} \\
0.53(0.04) \mathrm{d} \\
0.55(0.02) \mathrm{cd} \\
0.63(0.03) \mathrm{abc}\end{array}$ & $(6,633) 2.07,0.0549$ \\
\hline
\end{tabular}

$\mathrm{df}=$ degrees of freedom; Num $=$ numerator; Den $=$ denominator; $\mathrm{PW}=$ Proven Winners.

Significant differences between variable and effect means $(\alpha=0.05)$ are indicated by different lowercase letters. The analyses in this table were generated using the binomial distribution option of the GLIMMIX procedure of SAS software. (SAS and all other SAS Institute Inc. product or service names are registered trademarks or trademarks of SAS Institute Inc., Cary, NC)

Values in bold are significant at $P=0.05$ or lower.

the percentage who had purchased annual and perennial plants (Table 2). Compared with Brand Savvy Buyers, a higher percentage of Brand Reliant Buyers had made most of their purchases from an independent garden center and a lower percentage primarily purchased from a home improvement store. Areas in which they had differences from the other clusters were that members of this cluster had the highest agreement with the statement, "Nice garden centers and specialty stores offer me the best products" but the lowest agreement with the statement "Plants don't need to have a brand name to be high quality." Additionally, they ranked second in familiarity, experience, and knowledge of Proven Winners products (Table 7). Thus, the null $\mathrm{H} 1 \mathrm{a}$ and $\mathrm{H} 1 \mathrm{~b}$ were rejected since we did find
Brand Reliant Buyers, yet a higher percentage of Brand Reliant Buyers looked at the containers.

More differences were observed in the interaction effects (Fig. 2). For the Monrovia and Proven Winners brands, Brand Savvy Buyers were less likely to look at the brand. A higher percentage of Brand Reliant Buyers looked at Monrovia, Proven Winners, as well as the fictitious Unicorn brand, perhaps due to their lack of familiarity with the brands. There was no difference in the percentage of members of each cluster who looked at the no brand or generic container.

Next, the TFF and TFD on the branded and generic containers were compared. Both TFF and TFD were measured in milliseconds (ms) and only subjects who viewed the container (where the brand was depicted) were included in this analysis. There was no difference in the TFF among any of the brands, but subjects did view the generic (blank) container slower than the containers with the brands (Table 9). There were no differences by cluster, supporting the null $\mathrm{H} 4$ and H5. In addition, the TFD was longest on Proven Winners, followed by Monrovia, and lastly by no brand/generic. Unicorn had a TFD intermediate to the two established national brands, and, again, there was no difference by cluster.

For the academician and practitioner alike, purchase or purchase intention is the goal. Thus, we compared the LTB (purchase intention) overall and by cluster (Table 9). Overall, LTB was relatively high. However, members of clusters 1 and 3 expressed a higher mean LTB compared with cluster 2, rejecting $\mathrm{H} 1 \mathrm{c}$ and H3. Thus, some consumer groups were more likely to purchase the plants shown compared with others.

\section{Discussion}

tainers. This was a similar percentage to Brand Unaware Non-buyers, but higher than Brand Savvy Buyers. This was an interesting finding since more Brand Savvy Buyers had previously noticed the brands compared with 


\section{LS Means Estimate}

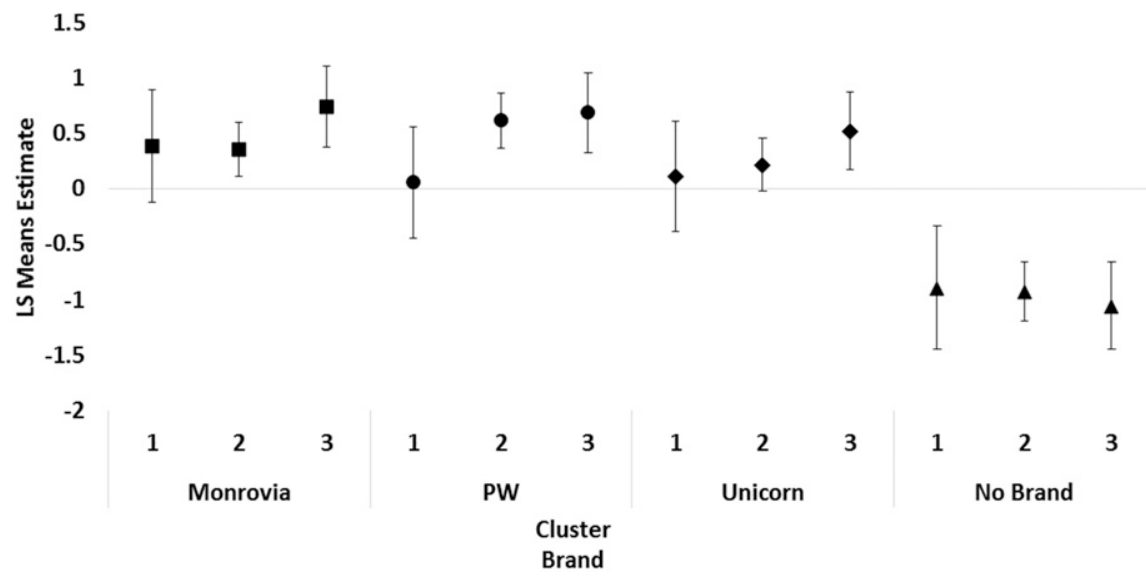

Fig. 2. Graphical representation of the brand by cluster interaction.

Table 9. Analysis of those who looked at the container by brand and cluster membership.

\begin{tabular}{|c|c|c|c|c|c|}
\hline \multirow{2}{*}{$\begin{array}{l}\text { Variable } \\
\text { Total fixation duration } \\
\text { on container }\end{array}$} & \multicolumn{3}{|c|}{ Effect } & \multirow{2}{*}{$\frac{\text { Mean (SE) }}{0.46(1.06)}$} & \multirow{2}{*}{$\begin{array}{c}\text { (df Num, Den) F, } P \\
(2,205) 0.25,0.7789\end{array}$} \\
\hline & Cluster & & 1 & & \\
\hline & & & 2 & $0.44(1.03)$ & \\
\hline & & & 3 & $0.45(1.04)$ & \\
\hline & Brand & & Monrovia & $0.47(1.04) b$ & $(3,476) 18.01,<0.0001$ \\
\hline & & & & $0.53(1.04) \mathrm{a}$ & \\
\hline & & & Unicorn & $0.53(1.05) a b$ & \\
\hline & & & No brand & $0.32(1.06) \mathrm{c}$ & \\
\hline & Cluster & rand & & & $(6,476) 0.42,0.8690$ \\
\hline \multirow{8}{*}{$\begin{array}{l}\text { Time to first fixation } \\
\text { on container }\end{array}$} & Cluster & & 1 & $1.02(1.06)$ & $(2,205) 0.52,0.5969$ \\
\hline & & & 2 & $1.03(1.03)$ & \\
\hline & & & 3 & $0.98(1.04)$ & \\
\hline & Brand & & Monrovia & $0.94(1.05) \mathrm{b}$ & $(3,470) 6.96,0.0001$ \\
\hline & & & & $0.87(1.05) \mathrm{b}$ & \\
\hline & & & Unicorn & $1.04(1.05) \mathrm{b}$ & \\
\hline & & & No brand & $1.23(1.07) \mathrm{a}$ & \\
\hline & Cluster & rand & & & $(6,470) 1.43,0.2004$ \\
\hline \multirow[t]{8}{*}{ Likely to buy } & Cluster & & 1 & $6.94(0.10) \mathrm{a}$ & $(2,211) 32.55,<0.0001$ \\
\hline & & & 2 & $6.33(0.06) b$ & \\
\hline & & & 3 & $7.00(0.07) \mathrm{a}$ & \\
\hline & Brand & & Monrovia & $6.76(0.09)$ & $(3,633) 0.96,0.4135$ \\
\hline & & & PW & $6.88(0.09)$ & \\
\hline & & & Unicorn & $6.71(0.09)$ & \\
\hline & & & No brand & $6.68(0.09)$ & \\
\hline & Cluster & rand & & & $(6,633) 0.16,0.9867$ \\
\hline
\end{tabular}

PW = Proven Winners.

Significant differences between variable and effect means $(\alpha=0.05)$ are indicated by different lowercase letters. The analyses in this table were generated using the GLIMMIX procedure of SAS software. (SAS and all other SAS Institute Inc. product or service names are registered trademarks or trademarks of SAS Institute Inc., Cary, NC.)

Values in bold are significant at $P=0.05$ or lower.

real national brands before the day of the study. Overall, subjects had a moderate level of brand awareness with $42 \%$ or less reporting they were not familiar with the brands. The moderate levels of brand familiarity and awareness were consistent with the fact that over half of the sample had purchased annuals (which the Proven Winners brand primarily markets) and $\approx 20 \%$ or fewer had purchased woody plants marketed by the have meaning to consumers. Brand Savvy Buyers had greater brand awareness and were as likely to buy the plants as Brand Reliant Buyers but more likely than Brand Unaware Non-buyers. Thus, we found support that consumers varied in their level of brand recognition, awareness, and purchase intention (rejecting $\mathrm{H} 1 \mathrm{a}, \mathrm{H} 1 \mathrm{~b}$, and $\mathrm{H} 1 \mathrm{c}$ ). This would indicate that a heterogeneous marketing strategy should be effective and those diverse preferences and behavior could be a ripe target for in-store POP marketing.

In the decision process, the conjoint results indicated consumers made their decision to buy (for this study measured as purchase intention) based primarily on the plant, which was consistent with prior studies (Behe et al., 2016; Behe et al., 2010; Behe et al., 2005b; Mason et al., 2008). The difference from Behe et al. (2016) was that price had a higher relative importance value compared with plant brand; this finding was consistent across all three clusters. The result here may have been due to the type of plants included in the study. Behe et al. (2016) used vegetable and herb transplants while the plants tested here were annuals and flowering shrubs. The only difference observed was that the Buddleia was valued more by Brand Savvy Buyers compared with Brand Unaware Non-buyers (and both were similar in relative importance to Brand Reliant Buyers).

The visual behavior was fairly consistent across the three cluster members. The branded containers were viewed faster (TFF) than the generic container and the brands were viewed for a similar duration of time (TFD). All brands, including the fictitious brand, attracted attention; this evidence did support $\mathrm{H} 4$ and H5. Overall, the Proven Winners brand and Unicorn brand held subjects' gaze similarly (TFD), with the Monrovia brand holding their gaze less than the Proven Winners brand. This finding was interesting from the standpoint that the Unicorn brand had substantially less brand awareness and recognition compared with both known national brands. Gaze time on an area of interest can be an important indicator of information processing (Fischer and Weber, 1993) or confusion (Shillcock et al., 2000). However, this visual attention did not lead to a higher likelihood to buy the plant since the mean purchase intention was similar for branded and generic products. This result contrasts prior literature where the amount of time spent looking at a certain area of a product can be an effective predictor of purchase behavior or intention (Armel et al., 2008; Behe et al., 2013; Clement et al., 2013; Lin and Chen, 2006). This may be due, in part, to the fact that plants are "minimally packaged" and a majority of the published literature used products in packaging (boxes and bottles).

Kotler and Keller (2009) posit that not all consumers act in the same manner, creating opportunities for market segmentation. In segmenting this sample, we did find some interesting differences by cluster membership. The $17 \%$ who Brand Savvy Buyers had 
substantially higher brand recognition (all had seen both real brands) and awareness. This awareness logically followed from a higher percentage of their members who had purchased various plant types, consistent with Collart et al. (2010). We found that, plants purchased by Brand Savvy Buyers were primarily from the home improvement store. Perhaps this cluster also expressed a higher mean LTB of the plants (mean $=6.94)$ compared with Brand Unaware Non-buyers because of their high level of prior purchases in terms of dollars spent and plant types bought. Alternatively, home improvement store purchases may be more likely to feature national plant brands than other retail channels. Surprisingly, a lower percentage of Brand Savvy Buyers looked at the brands, even the fictitious Unicorn brand; their focus was elsewhere and on the plant. With such a high level of brand recognition and awareness, we hypothesized that this group may use the brand cue more than other clusters. In fact, our finding was the opposite.

A similar percentage of Brand Unaware Non-buyers had seen the Monrovia brand, but very few of the members of this cluster had seen the Proven Winners brand. Thus, they had greater brand familiarity with Monrovia than Proven Winners. However, their brand familiarity with both national brands was substantially less than Brand Savvy Buyers. Their lower level of purchasing, and lower level of brand familiarity and awareness may have led to the lower LTB of any of the flowering plants; most had purchased vegetables or herbs which are products not widely marketed by either national brand. Since they primarily shopped at the supermarket, they may not have had as much exposure to these brands as they would at home improvement stores or independent garden centers.

Brand Reliant Buyers appeared to have many similar characteristics to Brand Savvy Buyers, but to a lesser extent. For example, Brand Savvy Buyers were older than Brand Unaware Non-buyers but younger than Brand Reliant Buyers. Brand Reliant Buyers had a higher percentage of brand recognition than Brand Unaware Non-buyers but less than Brand Savvy Buyers. That was true for Proven Winners brand but not Monrovia. A high percentage of Brand Reliant Buyers had purchased most of their plants and gardenrelated products at the independent garden center and a high percentage of them had purchased annuals and perennials, much like Brand Savvy Buyers.

\section{Conclusions}

Plant brands in this study did not influence purchase intention for our subjects. We did find that one national brand (Proven Winners) held attention as long as the fictitious brand (Unicorn) and slightly more than the other national brand (Monrovia). This may be due, in part, to the differences in investment in marketing the brand or curiosity or interest in the brand. While brand recognition and awareness did not appear to influence visual activity, the cluster with greater brand recognition and awareness, as well as higher average plant expenditures and types of plants purchased, were more likely to buy any of the plants shown. This finding may be because the plants were all digitally identical. The natural variation that may be found in branded plants compared with other brand or a generic plant was not there; and this may be a key limitation to the study.

Consumers in this study varied with regard to their brand recognition and awareness. This was related to the types of plants purchased, the amount spent on plant purchases, as well as the type of retailer from which the plant was purchased. From a practitioners' standpoint, current customers may be more like Brand Savvy Buyers and Brand Reliant Buyers because they spend a significant amount on the product category. Future customers may be more like members of Brand Unaware Non-buyers; they would be the next likely target market for branded plants. They have a lower level of brand recognition and awareness, but purchase plants like those marketed by the national brands. Still, few of the individuals from any segment were "fooled" by the fictitious brand. They were equally likely to recognize, be aware of, or buy the fictitious Unicorn brand, despite its ability to attract and hold the subject's visual gaze equally as well as the national brands.

All studies have limitations and the static images, limited number of brands, and plant types are among the two largest limitations. More research is needed in the retail setting with live plants to continue to add to our understanding of the role of plant brands in the purchase process.

\section{Literature Cited}

American Marketing Association. 2014. Dictionary. 27 July 2015. <https://www.ama.org/resources/ Pages/Dictionary.aspx>.

Armel, C., A. Beaumel, and A. Rangel. 2008. Biasing simple choices by manipulating relative visual attention. Judgm. Decis. Mak. 3:396-403.

Behe, B.K., P.T. Huddleston, and L. Sage. 2016. Age cohort influences brand recognition, awareness, and likelihood to buy vegetable and herb transplants. HortScience 51:145-151.

Behe, B., B. Campbell, J. Dennis, C. Hall, and R. Lopez. 2010. Gardening consumer segments vary in eco-practices. HortScience 45:14751479.

Behe, B.K., B.L. Campbell, C.R. Hall, H. Khachatryan, J.H. Dennis, and C. Yue. 2013. Consumer preferences for local and sustainable plant production characteristics. HortScience 48:209215.

Behe, B., J. Hardy, S. Barton, J. Brooker, T. Fernandez, C. Hall, J. Hicks, R. Hinson, P. Knight, R. McNiel, T. Page, B. Rowe, C. Safley, and R. Schutzki. 2005a. Landscape plant material, size, and design sophistication increase perceived home value. J. Environ. Hort. 23(3):127-133.

Behe, B.K., R.M. Walden, M. Duck, B. Cregg, K. Kelley, and R.D. Lineberger. 2005b. Consumer preferences for and cost of production of tabletop Christmas trees. HortScience 40: 409-412.

Bisson, L.F., A.L. Waterhouse, S.E. Ebeler, M.A. Walker, and J.T. Lapsley. 2002. The present and future of the international wine industry. Nature 418(8):696-699.

Butterfield, B. and I. Baldwin. 2015. National Gardening Survey. National Gardening Association, Williston, VT.

Brennan, M. and D. Esslemont. 1994. The accuracy of the Juster scale for predicting purchase rates of branded, fast-moving consumer goods. Mark. Bull. 5(5):47-52.

Chandon, P., J. Hutchinson, E. Bradlow, and S. Young. 2009. Does in-store marketing work? Effects of the number and position of shelf facings on brand attention and evaluation at the point of purchase. J. Mark. 73(6): $1-17$.

Chandon, P. and B. Wansink. 2002. When are stockpiled products consumed faster? A convenience-salience framework of postpurchase consumption incidence and quantity. J. Mktg. Res. 37(6):7-14.

Chaney, I.M. 2000. External search effort for wine. Intl. J. Wine Mktg. 12(2):5-21.

Chrzan, K. and B. Orme. 2000. An overview and comparison of design strategies for choicebased conjoint analysis. Sawtooth Software Research Paper Series. Sawtooth Software, Inc., Sequim, WA.

Collart, A.J., M.A. Palma, and C.R. Hall. 2010. Branding awareness and willingness to pay associated with the Texas Superstar and Earth-Kind brands in Texas. HortScience 45:1226-1231.

Clement, J., T. Kristensen, and K. Grønhaug. 2013. Understanding consumers' in-store visual perception: The influence of package design features on visual attention. J. Retailing Consum. Serv. 20:234-239.

Dodds, W. and K.B. Monroe. 1985. The effect of brand and price information on subjective product evaluations. Adv. Consum. Res. 12 (1):85-90.

Dodds, W., K.B. Monroe, and D. Grewal. 1991. Effects of price, brand, and store information on buyers' product evaluations. J. Mark. Res. 28(3):307-319.

Drèze, X., S.J. Hoch, and M.E. Park. 1993. Shelf management and space elasticity. J. Retailing 70:301-326.

Fetscherin, M. and D. Heinrich. 2015. Consumer brand relationships research: A biblometric citation meta-analysis. J. Bus. Res. 68(2):380 390.

Fischer, B. and H. Weber. 1993. Vision and visual attention. Behav. Brain Sci. 16:553-610.

Gaasbeck, A. and V. Bouwman. 1991. Conjoint analysis in market research for horticultural products. Acta Hort.: Hort. Econ. Mktg. 295: 121-125.

Getter, K.L. and B.K. Behe. 2013. Consumer willingness to purchase Impatiens walleriana alternatives. HortScience 48:1370-1377.

Hansen, F. 1969. Consumer choice behavior: An experimental approach. J. Mktg. Res. 6:436443.

Hartigan, J.A. 1975. Clustering algorithms. John Wiley and Sons, New York, NY.

Hodges, A., M. Palma, and C. Hall. 2009. Trade flows and marketing practices within the U.S. nursery industry, 2008. Southern Coop. Series Bull. no. 411. ISBN 1-58161-411.

Holmberg, I. 2002. Living trademarks, p. 83-92. In: L. Holger and I. Holmberg (eds.). Identity: Trademarks, logotypes and symbols.: National museum, Raster Forlag, Stockholm, Sweden. 
Hoyer, W.D. and S.P. Brown. 1990. Effects of brand awareness on choice for a common, repeat-purchase product. J. Consum. Res. 17(2): 141-148.

Jacob, R.J. 1990. What you look at is what you get: Eye movement-based interaction techniques, $\mathrm{p}$. 11-18. In: Proceedings of the SIGCHI conference on human factors in computing systems. ACM. 9 Feb. 2016. <http://blog.mersive.com/ wp-content/uploads/Robert-Jacob-What-youlook-at-is-what-you-get.pdf $>$.

Jacob, R.J. 1993. Eye movement-based humancomputer interaction techniques: Toward noncommand interfaces. Adv. Hum. Comput. Interact. 4:151-190.

Jacoby, J., J.C. Olson, and R.A. Haddock. 1971. Price, brand name and product composition characteristics as determinants of perceived quality. J. Appl. Psychol. 55:570-579.

Jacoby, J., D.E. Speller, and C.A. Kohn-Berning. 1974. Brand choice behavior as a function of information load: Replication and extension. J. Consum. Res. 1(1):33-42.

Jacoby, J., G. Szybillo, and J. Busato-Schach. 1977. Information acquisition behavior in brand choice situation. J. Consum. Res. 3:209-215.

Kapferer, J.N. 2012. The new strategic brand management: Advanced insights and strategic thinking. 5th ed. Kogan Page, London, UK.

Kardes, F.R., M.L. Cronley, J.J. Kellaris, and S.S. Posavac. 2004. The role of selective information processing in price-quality inference. J. Consum. Res. 31(2):368-374.

Keller, K.L. 2013. Strategic brand management: Building, measuring, and managing brand equity. 4th ed. Pearson Education, New Jersey, NJ.
Kotler, P. and K. Keller. 2009. Marketing management. 13th ed. Pearson Education Ltd. Essex, England.

Krippendorff, K. 2005. The semantic turn: A new foundation for design. CRC Press, Boca Raton, FL.

Kuhfeld, W.F. 2010. Marketing research methods in SAS. SAS Institute, Inc., Cary, NC.

Lin, L.Y. and C.S. Chen. 2006. The influence of the country-of-origin image, product knowledge and product involvement on consumer purchase decisions: An empirical study of insurance and catering services in Taiwan. J. Consum. Mark. 23(5):248-265.

Mason, S., T. Starman, R.D. Lineberger, and B.K. Behe. 2008. Consumer preferences for price, color harmony and care information of container gardens. HortScience 43:380-384.

Mintel. 2014. 14 June 2015. <http://www.mintel. $\operatorname{com} />$.

Nedungadi, P. 1990. Recall and consumer consideration sets: Influencing choice without altering brand associations. J. Consum. Res. 17(3):263276.

Olson, J.C. and J. Jacoby. 1972. Cue utilization in the quality perception process. In: M. Venkatesan (ed.). Proceedings, Third Annual Conference. The Association for Consumer Res. 2:167-179.

Pieters, R., M. Wedel, and R. Batra. 2010. The stopping power of advertising: Measures and effects of visual complexity. J. Mktg. 74(5):48-60.

Rihn, A., H. Khachatryan, B. Campbell, B. Behe, and C. Hall. 2015. Consumer response to novel indoor foliage plant attributes: Evidence from a conjoint experiment and gaze analysis. HortScience 50:1524-1530.
Rihn, A., H. Khachatryan, B. Campbell, C. Hall, and B. Behe. 2016. Consumer preferences for organic production methods and origin promotions on ornamental plants: Evidence from eye from eye-tracking experiments. Agr. Econ. 47:599-608.

Shillcock, R., T.M. Ellison, and P. Monaghan. 2000. Eye-fixation behavior, lexical storage, and visual word recognition in a split processing model. Psychol. Rev. 107:824851 .

Simon, H. 1974. How big is a chunk? Science 183:482-488

Ståhlberg, M. and V. Maila. 2012. Shopper marketing: How to increase purchase decisions at the point of sale. Kogan Limited, Philadelphia, PA.

U.S. Census. 2016. Quick facts, United States. 4 Oct. 2016. <https://www.census.gov/quickfacts/ table/PST045215/00>.

Wedel, M. and R. Pieters. 2008. A review of eye-tracking research in marketing, Vol. 4. p. 123-147. In: N.K. Malhotra (ed.). Review of marketing Research.

Wollaeger, H.M., K.L. Getter, and B.K. Behe. 2015. Consumer preferences for traditional, neonicotinoid-free, bee-friendly, or biological control pest management practices on floriculture crops. HortScience 50:721-732.

Yue, C., C.R. Hall, B.K. Behe, B.L. Campbell, R.G. Lopez, and J.H. Dennis. 2010. Are consumers willing to pay more for biodegradable containers than for plastic ones? Evidence from hypothetical conjoint analysis and non-hypothetical experimental auctions. J. of Ag. and Applied Econ. 42(4):757-772. 